\title{
THE REPRESENTATION OF JOKO WIDODO'S FIGURE IN THE JAKARTA POST
}

\author{
Eri Kurniawan \\ Amalia Dwi Utami \\ Universitas Pendidikan Indonesia \\ eri_kurniawan@upi.edu
}

First Received: 12 August 2016

Final Proof Received: 10 January 2017

\begin{abstract}
This research investigates the representation of Jokowi's figure as the governor of Jakarta, the presidential candidate, and the President of Indonesia in the Jakarta Post by using nomination and predication strategies of Discourse Historical Approach (DHA) proposed by Reisigl and Wodak (2001). Fifteen editorials focusing on Jokowi were examined. Findings reveal three main points. First, deixis and synecdoches become the nomination strategies that signify changes. The strategies signal that the Jakarta Post prefers to focus on Jokowi when he becomes the president since his every action represents the action that the government and Indonesia take. Second, the Jakarta Post prefers to use positive predication strategies in presenting Jokowi's figure in all categories except on the Corruption Eradication Commission (KPK) issue. Third, the signification of the representation indicates that nomination and predication strategies are employed to represent the shift in political support towards Jokowi: from positive to negative. The Jakarta Post supports Jokowi since his performance as a leader is in line with the Jakarta Post values. However, the Jakarta Post no longer gives him its full support on the KPK issue, for his action is seen to contradict the Jakarta Post's ideology that supports anticorruption movement.
\end{abstract}

Keywords: Jokowi; the Jakarta Post; discourse historical approach; nomination strategies; predication strategies

Joko "Jokowi" Widodo has become Indonesia's new media darling. He gains popularity for his unique 'street democracy' style of leading, starting from when he occupied a position as the mayor of Surakarta and when he became the Jakarta governor in 2012. In 2014, his popularity increased since he was nominated as the presidential candidate from the Indonesian Democratic Party of Struggle (PDIP). His nomination trigerred controversy because it transpired when he was still in charge of Jakarta. This controversy continued even after he won the election; barely a month since his inauguration, he decided to raise the fuel prices by an average of $30 \%$. His decision to nominate Comr. Gen. Budi Gunawan who has fat bank accounts as the National Police chief also caused an uproar. It happened since the case ended up with the criminalization of the Corruption Eradication Commission (KPK) leaders.

His popularity during his leadership, particularly as the governor of Jakarta, the presidential candidate, and the President of Indonesia, is reflected in the news reporting what he does. The mass media as the producers of the news have the responsibility to present the pros and the cons of what he does objectively (Cohen-Almagor, 2008). However, there is no such thing as being neutral in reporting news; news media will always have standpoints. It is because the news will always contain certain ideology (van Djik, 1988).
Therefore, news as part of media holds an important role to play in constructing what people think is real, interesting, beautiful, and moral (Matheson, 2005). In other words, news media have the power to change the point of view or ideology of a society (Trčková, 2011).

An example of the mass media's standpoint is displayed by the Jakarta Post. It openly declared the endorsement for Jokowi in the presidential election campaign through its editorial entitled "Endorsing Jokowi". The Jakarta Post argued that the endorsement was made as a moral choice and was not expected to sway votes ("Endorsing Jokowi", 2014). Nevertheless, the Jakarta Post had used its power to change the point of view of the society by presenting the purportedly good side of Jokowi during the campaign.

It is in the interest of this research to investigate how the Jakarta Post's editorials portray Jokowi's figure as the governor of Jakarta, the presidential candidate, and the President of Indonesia. Editorial is chosen to be analyzed since it represents the newspaper's opinion; i.e. the ideology of the newspaper (van Djik, 1988). One of the approaches that can be used to investigate this issue is Discourse Historical Approach (DHA) proposed by Reisigl and Wodak (2001). By employing DHA, this research explores how discursive strategies, especially nomination and predication strategies, are used by the mass media in (re)presenting Jokowi. 
Representation relates to the process of how the mass media construct someone's figure. From discourse analysis perspective, representation refers to the way language is employed in a text to express the underlying meanings of the descriptions of people, places, or social practices (van Dijk, 2002). The representation of immigrants as people who have a higher birth-rate in a text, for instance, can be used to show that they are deemed 'problems'.

Representation determines the way people think about particular objects, events, situations, and even social practices (Signes, 2007). However, it should be noted that representation is not always described objectively; it depends on the group who has the power to represent and disseminate particular meaning (Vihersalo, 2009). The group then decides "what is to be taken as the correct, appropriate, or preferred representation" (Holquist, 1983; Fairclough, 1992; Wodak, 2001 as cited in Wenden, 2005, p. 90). As a result, representation is often manipulated, exaggerated, or distorted (Signes, 2007).

Another concept that is important in this research is Critical Discourse Analysis (CDA). To understand the concept of CDA, it is necessary to see how CDA defines discourse. Discourse is not simply an isolated textual or dialogical structure (van Dijk, 1988). It is seen as socially constructed ways that do not only shape but also enable (social) reality (Foucault, 1977; Paltridge, 2006). It also helps to establish power relations between social classes, gender, or majority and minority groups (Wodak \& Meyer, 2009). Therefore, CDA acts as an approach that critically investigates the relationship between discourse and the reproduction of power in social practices and interactions (Fairclough, 1995 as cited in Mancini, 2011).

CDA develops into many approaches that emerge with their own characteristics. They are Dispositive Analysis (Jäger and Maier), Sociocognitive Approach (van Dijk), Social Actors Approach (van Leeuwen), Dialectical-Relational Approach (Fairclough), and Discourse Historical Approach (Wodak). The last approach, Discourse Historical Approach (DHA), focuses on political issues by emphasizing on the historical dimension of the issues and the background of the social and political fields within which the issues are embedded (van Leeuwen \& Wodak, 1999; Wodak, 2010).

DHA considers the historical and current context of the subject investigated important as they deconstruct intertextual and interdiscursive relations of the subject. Intertextuality refers to the relation of one text to other texts where a text may implicitly or explicitly cite the others, both in the past and in the present (Paltridge, 2006). On the other hand, interdiscursivity denotes the connection between discourses in various ways through explicit or implicit references (Wodak \& Forchtner, 2014).
In analyzing a specific discourse and related texts, DHA uses discursive strategies as the tools. Discursive strategy means an elaborate and systematic ways of using language to reach a particular social, political, psychological, or linguistic goal (Wodak \& Meyer, 2009). Discursive strategy consists of five strategies: nomination, predication, argumentation, perspectivization, and intensification. Out of those five discursive strategies mentioned above, this research focuses on two strategies, namely nomination and predication strategies.

Nomination strategy is a strategy in using linguistic devices to refer to persons, things, places, or event. By using this strategy, the speaker or writer can reveal political, social, or psychological interests or purposes (Reisigl \& Wodak, 2001). There are many linguistic devices that can be used in this strategy; for instance, through membership categorization devices such as deixis, anthroponym, and metonymic. The analysis can also be done by using metaphor and synecdoche (Wodak \& Meyer, 2009).

After being identified by nomination strategy, the persons, things, places, or events are analyzed by using predication strategy. Predication strategy is a strategy in attaching persons, animals, or objects with some qualities or characteristics. This strategy is aimed at representing social actors more or less positively or negatively (Reisigl \& Wodak, 2001). The strategy is realized by stereotypical, evaluative attribution (in the form of adjective, relative clause, infinitive phrase, and prepositional phrase), explicit, collocation, rhetorical figure (including hyperboles and litotes), and allusion (Wodak \& Meyer, 2009).

Literature shows that there have been volumes of studies that employ DHA, for instance, van Leeuwen and Wodak (1999) who investigate the rejection of Austrian immigrants' family reunion applications by combining DHA with systemicfunctional linguistics. Unger (2010) studies how language ideologies about Scots language are realized linguistically. Meanwhile, Chiu and Chiang (2012) examine the use of metaphor in the representation of people's name rectification movement of Taiwan's indigenous in newspaper. DHA is also used by Larasati (2014) and Lacerda (2015) to investigate news. While Larasati (2014) focuses on war discourse, Lacerda (2015) centers the analysis on the political discourse on favelas (slums).

Nevertheless, it remains a difficult task to locate studies about important people in the mass media, especially in Indonesian context, that employ DHA. Given that particular reason, this research explores how discursive strategies, especially nomination and predication strategies, are used by the mass media in presenting Jokowi. In particular, the present research is conducted to answer the following questions: (i) How is Joko Widodo as the 
governor of Jakarta and the President of Indonesia during his first months leadership and as the presidential candidate represented through nomination and predication strategies in the selected editorials?; and (ii) What does the representation signify?

\section{METHODS}

Consistent with the nature of the research questions, this research employed a descriptive qualitative method because "the focus of qualitative approach is to understand how meanings are (re)constructed" (Merriam, 2009, p. 13). In analyzing the data, Discourse Historical Approach (DHA) proposed by Reisigl and Wodak (2001) was employed. Specifically, the analysis focused on nomination and predication strategies. The analysis of nomination strategy is aimed at seeing how Jokowi is referred to, while the analysis of predication strategy is used to see how Jokowi is represented through some characteristics attached to him.

The data used in this research were taken from www.thejakartapost.com. The Jakarta Post is selected since it is the largest daily English newspaper in Indonesia that has won several awards for its credibility (Aryuni, 2012). Moreover, it openly declared its endorsement for Jokowi in the presidential election campaign through its editorial entitled "Endorsing Jokowi" that shows its standpoint toward Jokowi.

The number of editorials taken as samples was 15. Fifteen editorials were considered sufficient since an in-depth analysis was called for. They were purposely selected based on the variance and the importance of their contents. Moreover, they represent the change of Jokowi's roles in the government: as the Jakarta governor, the presidential candidate, and the President of Indonesia. The editorials of Jokowi as the president were then divided into three categories: (i) Jokowi during his first month leadership as the president, (ii) the fuel-prices hike issue, and (iii) the KPK issue. Therefore, the total of categories analyzed was five categories, with three editorials for each category. The editorials were published from October 2012 to March 2015.

The data were analyzed by using DHA's nomination and predication strategies. There were a number of steps used in conducting the investigation. First was identification of the nomination strategies employed by the Jakarta Post in referring to Jokowi using linguistic devices. The linguistic devices found were then classified based on the types of nomination strategy proposed by Reisigl and Wodak (2001).

Second was examination of the predication strategies used by the Jakarta Post in representing Jokowi. This was done to see how the Post represents Jokowi by ascribing some characterizations to him. The predication strategies found in the editorials were classified based on the types of predication strategy proposed by Reisigl and Wodak (2001).

Last was comparison of the results of the nomination and predication strategies of all categories to see the overall signification of the selected editorials. This research is aimed to see whether there is any change in nomination and predication strategies employed by the Jakarta Post in representing Jokowi as the governor of Jakarta, the presidential candidate, and the President of Indonesia.

\section{FINDINGS AND DISCUSSIONS}

The findings of this research are presented in three main parts, namely nomination strategies, predication strategies, and signification of the representation.

\section{Nomination Strategies}

According to the analysis of fifteen editorials about Jokowi as the Jakarta governor, the presidential candidate, and the President of Indonesia, five nomination strategies are used by the Jakarta Post. They are deixis, proper name, professional anthroponym, noun, and synecdoche. Among all nomination strategies, three strategies become the most frequent nomination strategies used by the Jakarta Post, namely deixis, proper names, and professional anthroponyms. In addition to the three strategies, there is another strategy acting as a prominent strategy, synecdoches.

Deixis becomes the most frequent nomination strategy used to refer to Jokowi (34.48\%). It seems the Jakarta Post uses deixis to avoid repetition of the same proper name throughout the text. Specifically, the Jakarta Post employs personal deixis. Personal deixis is chosen since it helps construct the social relationship (Bello, 2013), which in this case the relation between the Jakarta Post and Jokowi, especially through the use of deixis 'he', 'his', 'they', and 'their'. By employing them, the Jakarta Post suggests that its position is neither close nor distant. The relationship will be different if it uses deixis such as 'we,' indicating a collective sense of belonging between the Jakarta Post and Jokowi or 'they' in the context of comparing 'we' and 'they' showing exclusion (Adegoju, 2014; Belo, 2013; Kim, 2014).

It is also found that there are changes in the use of deixis 'he', 'his', 'they', and 'their'. 'He' and 'his' are applied in all categories except in the presidential election where Kalla is always mentioned alongside Jokowi. On the other hand, deixis 'they' and 'their' used as the reference when Jokowi is mentioned with Ahok, and Kalla only appears in two categories: Jokowi as the governor 
and the presidential candidate, as illustrated in Table 1.

The following examples show how the Jakarta Post mentions Ahok and Kalla along with Jokowi:

[1] But the public's daily fatigue and frustration will nevertheless require adept skills from Jokowi and his deputy in managing expectations, in which they have a basic advantage ("Welcome Governor Jokowi", 2012).

[2] The economic components of the platform put forth by presidential candidate Joko "Jokowi" Widodo and his running mate Jusuf Kalla reflect the right priorities that the nation really needs as they focus on food, energy and infrastructure ("The Jokowi-Kalla platform", 2014).

Table 1. Appearances of deixis 'they' and 'their'

\begin{tabular}{ccc}
\hline Category & F of 'They' & F of 'Their' \\
\hline As the governor (Jokowi and Ahok) & 5 & 1 \\
\hline $\begin{array}{c}\text { Presidential election } \\
\text { (Jokowi and Kalla) }\end{array}$ & 1 & 3 \\
\hline First month as the president & 0 & 0 \\
\hline Fuel-price hike issue & 0 & 0 \\
\hline The KPK issue & 0 & 0 \\
\hline
\end{tabular}

The way the Jakarta Post attaches Ahok to Jokowi in example [1] suggests that the Jakarta Post does not solely focus on Jokowi as the main role but emphasizes that Ahok has a part too. Meanwhile, the way Kalla is mentioned together with Jokowi in example [2] implies that they are a pair who works together. It also denotes that the plans offered are the representation of their thoughts and therefore the plans will be executed by both.

As Table 1 illustrates, the Jakarta Post does not mention Kalla as the vice president along with Jokowi when they have been chosen for the presidential seats. It implies that the Jakarta Post does not try to underline who the vice president is and his role in the government, as it does in the governor period. It may also mean that after Jokowi and Kalla are elected, Jokowi is the one who has the control to execute the government's programs. As a result, the Jakarta Post prefers to only utilize deixis 'he' so the readers know that the one who will be either praised or blamed for the performance of the government is Jokowi, not Jokowi and Kalla.

After deixis, proper names become the most frequent nomination strategy used to refer to Jokowi $(32.76 \%)$. [3] provides an example.

[3] The relocation has been delayed for more than one year as the related ministries under Yudhoyono's administration were very slow to process the administrative documents. Jokowi also distributed Indonesia Smart Cards (KIP), Indonesia Prosperous Family Cards (KKS) and Indonesia Health Cards (KIS). (“Jokowi’s Hot Porridge", 2014).

As apparent from the above data, the word Jokowi is employed to refer to the President in order to show to the readers which person becomes the center of the text, especially when another name is mentioned, i.e. Yudhoyono. The strategy is also used when the reference of the action is not mentioned in the immediately preceding sentence (Fukumura \& van Gompel, 2012). Moreover, the use of the nomination strategy also indicates that the Jakarta Post tries to avoid ambiguity.

Another strategy is displayed by professional anthroponyms $(25.86 \%)$. By using this strategy, the Jakarta Post tries to put forward Jokowi's professionalism side instead of his other side, as a family man for example. The decision to apply professional anthroponyms is also related to the purpose of the editorial that is to describe and report Jokowi's action regarding his job. When Jokowi is elected as the new governor, the Jakarta Post displays him as 'the governor' who is in charge of Jakarta. The realization of the strategy then changes as Jokowi is proposed to be the presidential candidate, as evident below.

[4] Business people should feel confident after examining the economic platforms presented by presidential candidate Joko "Jokowi" Widodo and his running mate, Jusuf Kalla, as well as noting their off the cuff responses to questions regarding their stance on the role of the private sector ("Business-friendly candidates", 2014).

Another prominent strategy is synecdoche. Although the frequency is considered low, but synecdoches become important to discuss since the strategy only occurs when Jokowi becomes the president, especially in his first month as a president and fuel-price hike issue, as portrayed in Table 2.

As the table displays, synecdoches are realized by using the words 'government' and 'Indonesia'. Synecdoche 'government' is used when the program is intended for Indonesian people, while synecdoche 'Indonesia' is applied when the program is designed for international relationship. They are classified into synecdoche since they are used to denote a whole country referring to Jokowi. 
Table 2. Appearances of synecdoches

\begin{tabular}{ccc}
\hline Category & Realization & F \\
\hline As the governor & - & 0 \\
\hline Presidential election & - & 0 \\
\hline \multirow{2}{*}{ First month as the president } & The government & 1 \\
\cline { 2 - 3 } & Indonesia & 1 \\
\hline Fuel-price hike issue & The government & 3 \\
\hline The KPK issue & - & 0 \\
\hline
\end{tabular}

The examples of how the words 'government' and 'Indonesia' are used are represented in examples [5] and [6]:

[5] For its part, the government has insisted that the decision was its prerogative and was urgently made to save some Rp 300 trillion (US\$ 24.8 billion) ("The Oily Politics of Fuel", 2014).

[6] His straightforward diplomacy may look strange given his Javanese upbringing, but the world now knows what Indonesia wants and offers ("When Jokowi Steals the Show", 2014).

In example [5], the Jakarta Post implies that the decision to raise subsidized fuel prices is initially proposed by Jokowi in his presidential campaign as the decision made by 'the government'. Meanwhile, 'Indonesia' in example [6] is employed as a reference to Jokowi who unveils his government's plan in an international forum, so the world knows that he speaks on Indonesia's behalf. By using this strategy, the Jakarta Post tries to draw the attention to Jokowi's position as the president; hence, his every action represents the action that the government and Indonesia take.

\section{Predication Strategies}

According to the analysis of fifteen editorials about Jokowi, he is assigned different characteristics, qualities, and features. They are realized by using predications that can represent the Jakarta Post's judgment on Jokowi's figure. The predications used are divided based on the categories of his roles in the government and issues when he becomes the president. They are further classified based on the positive and negative tendencies, as demonstrated in Figure 1.

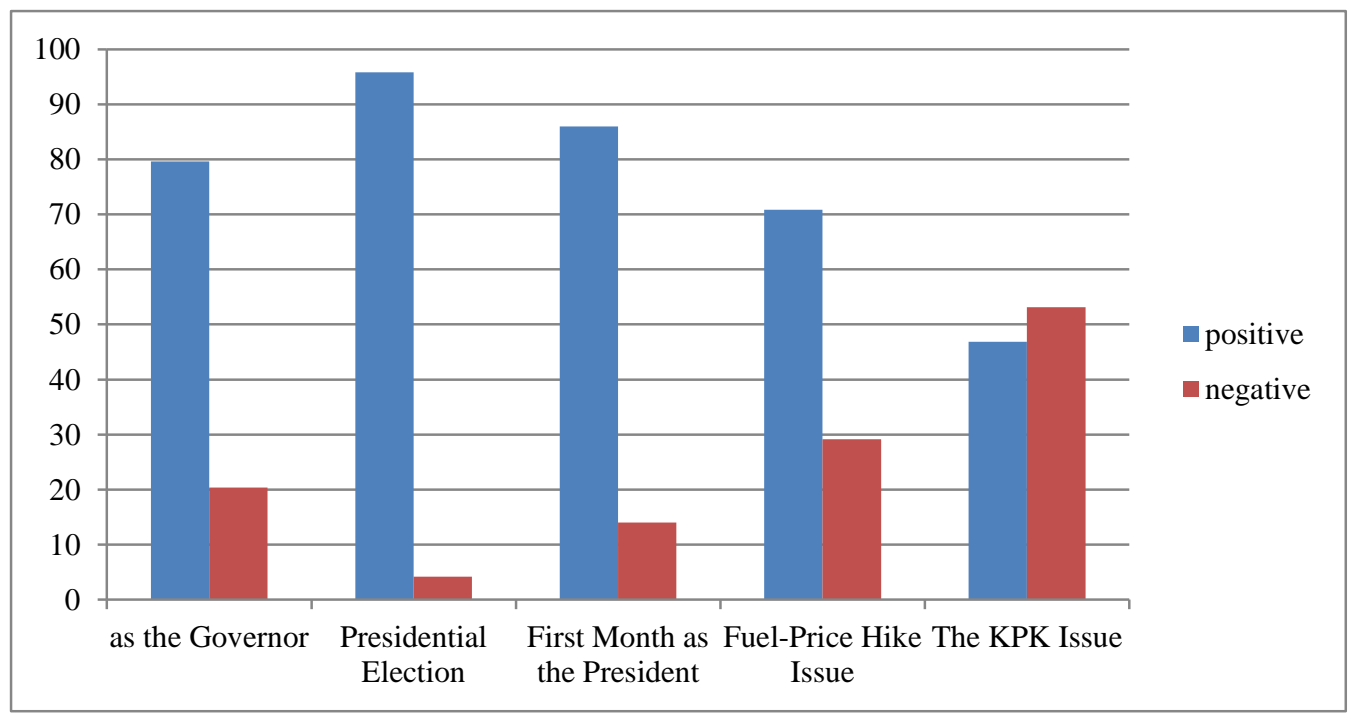

Figure 1. The Jakarta Post's shift in political support towards Jokowi

As it is displayed, the Jakarta Post constructs Jokowi by means of positive and negative predications. Figure 1 shows that the percentage of positive and negative predications in each category changes. When Jokowi occupies a position as the Jakarta governor, the percentage of positive predications reaches $79.63 \%$. The percentage rises significantly when he is nominated as the presidential candidate $(95.83 \%)$. However, it gradually falls after he becomes the president, while the percentage of negative predications continues to increase. Eventually, the percentage of negative predications used reaches $53.13 \%$ when he is confronted with the KPK issue. In other words, the Jakarta Post prefers using positive predications in presenting Jokowi's figure in all categories except in the KPK issue. The alteration of how positive and negative predications are used implies the Jakarta Post's shift in political support towards Jokowi. It means that the Jakarta Post no longer gives Jokowi its full support regarding the KPK issue.

In addition to the analysis of the positive and negative judgment of the predications, the category of each predication is also analyzed. The results 
show that the predications are classified into six predication strategies, namely explicit predicate, adjective, relative clause, infinitive phrase, prepositional phrase, and hyperbole. However, among all predication strategies, only two strategies are used in all categories, namely explicit predicate and adjective. The two strategies also appear to be the most frequent predication strategies used by the Jakarta Post.

Explicit predicates become the most frequent predication strategy used to present Jokowi's characteristics $(79.58 \%)$. The strategy is employed to convey the main idea of each sentence. It is also utilized since it can describe the action and the state of Jokowi; it does not merely describe additional information about him. For the same reasons, explicit predicates become the means for the Jakarta Post to express its political standpoint, whether to support or to oppose Jokowi.

The examples of explicit predicates that contain evaluative attributions of positive traits are 'maintained the speed his work' and 'captivated many' in an editorial entitled "A tale of two Anases" (2013) when he becomes the Jakarta governor. The predicate 'maintained the speed his work' projects the Jakarta Post's belief that Jokowi has performed well as a governor. Moreover, the Jakarta Post employs a strong predicate such as 'captivated' to depict Jokowi as a charming leader who has held people's attention, including those living outside Jakarta and in his hometown of Surakarta.

Explicit predicates containing positive judgment are also applied in the editorials of Jokowi when he is appointed as the presidential candidate supported by Great Indonesia Coalition. During this period, Jokowi is described as a servant of democracy that will not do the same thing like what his predecessor Soeharto did, an implication embedded in the explicit predicate 'offers a break from the past' ("Endorsing Jokowi”, 2014).

The Jakarta Post continues to use positive explicit predicates to portray Jokowi as a good president in the first month of his leadership. During this period, there is one characteristic highlighted by the Jakarta Post: Jokowi does not like to obey rigid rules. However, it is his neglect of the rules that helps him do his work, as exemplified below:

[7] On Wednesday, thousands of refugees cheerfully welcomed the President, who neglected much of the rigid protocol restrictions imposed by his predecessor Susilo Bambang Yudhoyono during his 10 year tenure ("Jokowi's Hot Porridge", 2014).

Afterwards, the Jakarta Post still gives Jokowi its support when Jokowi makes an unpopular policy to raise fuel prices. The Jakarta Post believes that raising the fuel prices is necessary to save the government's budget. Therefore, it compliments
Jokowi for his decision to raise the fuel prices through the explicit predicate 'has shown his leadership and character' ("Fuel-Price Hike, Finally", 2014). The explicit predicate also implies Jokowi's capacity as a leader who proves his good quality by making the unpopular decision.

As Figure 1 displays, predications are not only employed to depict the positive representation of Jokowi's figure in each category. They are also utilized to depict the negative one, as can be seen in the KPK issue. During this period, the percentage of negative predications reaches $53.13 \%$. It appears that the Jakarta Post is disappointed by Jokowi's decision to nominate Comr. Gen. Budi Gunawan as the National Police chief. Moreover, this issue at the end leads to the assault on the KPK. An occurrence of explicit predicate with negative judgment in this period is denoted in the example [8]:

[8] Or perhaps he just does not care, and uses the guise of non-interference to mask his real thoughts ("Who will save the KPK?", 2015).

The example above implies that Jokowi is a bad leader who protects his own image by pronouncing that he must not interfere with the KPK-police row; it is important for him to be neutral. The predicates also mean that he avoids his responsibility to save the KPK acting as the antigraft institution in Indonesia.

After explicit predicates, adjectives become the most frequent predication strategy used to refer to Jokowi (10.99\%). It appears that the strategy is utilized in order to describe what kind of leader Jokowi is. Furthermore, adjectives are applied to inform the readers about the Jakarta Post's particular opinion with positive and negative tendencies about the programs proposed by Jokowi. However, it should be noted that unlike the positive and negative judgment that can be found in the choice of explicit predicates in every category, the same does not apply to adjectives. The results show that in the governor and presidential election periods, adjectives are only employed as the strategy that carries positive judgment. On the contrary, adjectives are only used to describe negative characteristics and features of Jokowi in the fuelprice hike and the KPK issue.

The examples of adjective that contain evaluative attributions of positive traits are 'ambitious but not impossible' and 'quite strategic' ("The Jokowi-Kalla platform", 2014). They are used to project the Jakarta Post's belief that Jokowi and Kalla have a strong wish to make Indonesia better. Moreover, by using the adjective the Jakarta Post implies that the pair has a clear image of the important things needed to be done; they understand the way to achieve their aim.

On the other hand, two adjectives found in the KPK issue period are classified into negative 
category. Example [9] below instantiates the use of negative adjective:

[9] His recent statement that highlighted prevention as the focus of the fight against graft indicates he is not aware ("Who will save the KPK?", 2015).

The example signifies that he does not realize of the main problems that he faces since he only focuses on its prevention. The adjective can also be interpreted that he does not give attention to the anticorruption movement.

The analysis of explicit predicates and adjectives also displays that Jokowi is always contrasted with other politicians in all categories. When Jokowi occupies a position as the Jakarta governor, he is compared with Fauzi Bowo, the former Jakarta governor. Jokowi is said as 'more approachable' ("Welcome Governor Jokowi”, 2012) since he has a unique style of leading that becomes his means to communicate with his people directly, called 'street democracy' or blusukan. Meanwhile during the presidential election, he is contrasted with Prabowo, another presidential candidate. It seems the full support for Jokowi is motivated by the assumption that Jokowi's performance as a leader is in line with the Jakarta Post's values that are "pluralism, human rights, civil society, and reformasi" ("Endorsing Jokowi", 2014, para. 11). Furthermore, the Jakarta Post considers supporting Prabowo as morally wrong. It believes that his move to affiliate with hardline Islamic groups will only taint democracy in Indonesia.

Afterwards, Jokowi is contrasted with the former President of Indonesia, Susilo Bambang Yudhoyono, when he is elected as the new president. While Yudhoyono is presented as someone who complies with the protocol, Jokowi is displayed as someone who does not stick with it. The comparison between them somehow leaves the readers with an impression that Yudhoyono attempts to put some distance between him and his people. They are also compared regarding the fuel-price hike issue. Unlike Jokowi who 'has shown his leadership and character', Yudhoyono is depicted as a leader who does not have the courage to raise the fuel prices since it will taint his image. They are also compared when the KPK is criminalized. The Jakarta Post expresses that unlike what Jokowi does regarding Bambang Widjojanto and Abraham Samad's investigation, Yudhoyono devotes his attention to the issue related to the KPK. His interference in the police investigation of a KPK's staff proves that he is consistent with his pledge to fight corruption in Indonesia.

\section{Signification of the Representation}

Since this research employs DHA as its approach, it analyzes the selected editorials by relating them to historical background. The historical background is realized through Jokowi's positions as the Jakarta governor, the presidential candidate, the president in his first month leadership, the president who raises the fuel prices, and the president who is confronted with the KPK issue. Focusing on the discursive strategies, this research finds that there are changes in two nomination strategies used to refer to Jokowi, namely deixis and synecdoches. For instance, in terms of deixis, 'they' and 'their' are only used as the references when Jokowi is mentioned with Ahok when he becomes the governor and with Kalla when he becomes the presidential candidate. However, a shift from the use of 'they' and 'their' to 'he' and 'his' takes place after Jokowi is elected as the President of Indonesia. This alternation of deixis may signify that the Post wants the readers to know that when Jokowi becomes the president, he alone is the one who has the control to execute the government's programs. Synecdoches as a nomination strategy only appear after Jokowi is elected as the new president, realized through the word 'government' and 'Indonesia'. By using this strategy, the Jakarta Post tries to draw the attention to Jokowi's position as the president. Therefore, his every action represents the action that the government and Indonesia take.

This research also finds that the predication strategies also change due to the historical background. The Jakarta Post prefers using positive predications in presenting Jokowi's figure in all categories except on the KPK issue. In addition, the analysis of the predication strategies demonstrates that Jokowi is always contrasted with other politicians in all categories. The results show that all comparisons are employed by the Jakarta Post to underscore Jokowi's positive images in all categories except on the KPK issue. In other words, in all issues but KPK issue, the Post gives its fullfledged support to Jokowi in the different roles he has, i.e. as a governor, presidential candidate, and the president.

When Jokowi occupies a position as the Jakarta governor, he gains the Jakarta Post's good impression. It is caused by his unique style of leading that becomes his means to communicate with his people directly, called 'street democracy' or blusukan. The Jakarta Post then gives its support when he is nominated as the presidential candidate through the editorial entitled "Endorsing Jokowi". The reason behind the endorsement is that Jokowi's performance as a leader is in line with the Jakarta Post values: "pluralism, human rights, civil society, and reformasi" ("Endorsing Jokowi", 2014, para. 11). During this period, he is contrasted with Prabowo, another presidential candidate, and even Soeharto, the second President of Indonesia.

Historically, the Jakarta Post refers to Prabowo as a Former Army Special Forces (Kopassus) commander who is accused for 
kidnapping and murdering activists opposed to the Soeharto regime in May 1998 ("Stop Empty Promises", 2009; "Voters' Right to Know", 2014). The contradiction between what Prabowo does and the Jakarta Post's ideology related to human rights thus effects on its antagonism toward Prabowo's nomination on the 2009 and 2014 presidential election. The Jakarta Post believes that if Prabowo is elected as president, he will only romanticize Soeharto era. The belief emerges since Soeharto has also violated human rights by using military power. Explicitly, Soeharto is described as a dictator who uses his power to control the government through his military-controlled party, The Functional Group Party (Golkar Party) ("And the Winner is ... the Junta", 2010). Moreover, the Jakarta Post considers that he has violated basic rights by instructing the military and police to kill thousands of preman (hoodlums) throughout the country, known as petrus or mysterious shootings ("Soeharto's Repeated War", 2008).

Meanwhile, the Jakarta Post's support for President Jokowi for his courage to raise the fuel price is related with its view on the fuel issue. Since Yudhoyono's leadership, it argues that increasing the fuel prices is important to avoid more export smuggling and misuse by industrial users. Besides, the subsidized fuel only benefits the middle and upper-middle income groups ("The Fuel Subsidy Trap", 2008). Hence, the Jakarta Post criticizes Yudhoyono's decision to not increase the fuel prices for the sake of his nomination in the 2009 presidential election by stating, "Yudhoyono and his Democratic Party has been exploiting the government's moves in lowering fuel prices for propping up his popularity" ("Shake-up at Pertamina", 2009, para. 5).

Moreover, the Jakarta Post judges that Yudhoyono's decision to not increase the fuel prices in the end of his second period leadership is only made to give a good impression for him and his political party. By doing so, Yudhoyono leaves behind 'a ticking time bomb' that his successor must handle ("The Great Oil Conspiracy", 2013). Therefore, the Jakarta Post praises Jokowi for risking his popularity during his first month leadership by reducing the fuel subsidies, although the members of his own political party oppose the idea. It is a brave move since his decision "will cut short his honeymoon period" ("Fuel Price Hike Looms for Indonesia's New Leader", 2014, para. 5).

However, the Jakarta Post no longer gives Jokowi its support regarding the KPK issue. As a mass media outlet supporting anticorruption movement, the Jakarta Post asserts its disappointment to Jokowi who lets the police's continuing assault on the KPK by attaching him with negative predications. On the other hand, it supports Yudhoyono by attaching him with positive predications in the comparison between him and
Jokowi. It seems Yudhoyono's good representation is closely related with what he has done for the KPK. In 2009, for instance, Yudhoyono supports the KPK's authority to prosecute offenders and use wiretaps ("SBY Supports KPK's Authority to Prosecute", 2009). His statement is related to Comr. Gen. Susno Djuadji case, where Djuadji accuses the KPK of tapping his cell phone revealing him demanding IDR 10 billion bribe in the Bank Century scandal. The case leads to the arrest of the KPK leaders, Bibit and Chandra, by the police. Regarding the arrest, Yudhoyono says that he will defend the KPK from those who try to phase it out ("Calls Mount for Bambang, Susno Djuadji to Resign", 2009).

In 2012, the police attempted to arrest Comr. Novel Baswedan for misconduct in 2004. Baswedan is one of the KPK's investigators who handled the driving simulation case involving Insp. Gen. Djoko Susilo. Therefore, the police's action is believed as their move to undermine the antigraft institution. Yudhoyono then interferes in the case to allow Baswedan to continue his investigation ("Yudhoyono's Kudo for KPK", 2012).

Of particular interest with respect to the representations of Jokowi's figure in five categories, as evident from the analysis of nomination and predication strategies, is the shift in the Post's political support towards Jokowi: from positive to negative. The Jakarta Post supports Jokowi since he becomes the Jakarta governor until he is chosen as the seventh President of Indonesia. However, the Jakarta Post changes its stance on Jokowi on the KPK issue, for Jokowi's action or decision is viewed to contradict the Jakarta Post's ideology or values that support anticorruption movement. If the Jakarta Post should make a choice between Jokowi and the KPK, it will certainly choose the KPK and those who support the antigraft institution. It is evidenced by the way the Post portrays Yudhoyono positively regarding his action to defend the KPK when he runs the office.

\section{CONCLUSIONS}

This research examines the representation of Jokowi as the governor of Jakarta, the presidential candidate, and the President of Indonesia in the Jakarta Post. Specifically, this research investigates how nomination and predication strategies are employed by the Jakarta Post in presenting Jokowi's figure. In addition, this research also analyzes the signification of the representation.

According to the analysis of nomination strategies, deixis and synecdoches become the strategies that undergo changes. The strategies signal that the Jakarta Post prefers to focus on Jokowi when he becomes the president since his every action represents the action that the government and Indonesia take. This research also 
finds that the predication strategies also change due to the historical background. The Jakarta Post prefers to use positive predications in presenting Jokowi's figure in all categories except in the KPK issue. The same result is also displayed by the comparisons between Jokowi and other politicians where they are used to emphasize Jokowi's positive representation in all categories except on the KPK issue.

The signification of the representation indicates that nomination and predication strategies are employed to represent the shift in political support towards Jokowi: from positive to negative. The Jakarta Post supports Jokowi since he becomes the Jakarta governor until he is chosen as the seventh President of Indonesia because Jokowi's performance as a leader is in line with the Jakarta Post values. However, the Jakarta Post no longer gives him its full support on the KPK issue, as his action is seen to contradict the Jakarta Post's ideology that supports anticorruption movement.

\section{REFERENCES}

Adegoju, A. (2014). Person deixis as discursive practice in Nigeria's "June 12" conflict rhetoric. Ghana Journal of Linguistics, 3(1), 45-64.

Aryuni, H. (2012). An analysis of political cartoons in the Jakarta Post e-paper (a semiotic discursive approach). (Unpublished bachelor's thesis). Dian Nuswantoro University, Semarang, Indonesia.

Bello, U. (2013). "If I could make it, you too can make it!" personal pronouns in political discourse: A CDA of President Jonathan's presidential declaration speech. International Journal of English Linguistics, 3(6), 84-96. doi:10.5539/ijel.v3n6p84.

Chiu, S., \& Chiang, W. (2012). Representations of the name rectification movement of Taiwan indigenous people: Through whose historical lens? Language and Linguistics, 13(3), 523568.

Cohen-Almagor, R. (2008). The limits of objective reporting. Journal of Language and Politics, 7(1), 138-157.

Foucault, M. (1977). Language, counter-memory, practice: Selected essays and interviews. Ithaca: Cornell University Press.

Fukumura, K., \& van Gompel, R. P. G. (2012). Producing pronouns and definite noun phrases: Do speakers use the addressee's discourse model? Cognitive Science, 36, 1289-1311. doi: 10.1111/j.1551-6709.2012.01255.x.

Kim, J. (2014). The politics of inclusion/exclusion: Critical discourse analysis on multicultural education policy documents in South Korea. Multicultural Education Review, 6(2), 1-24.
Lacerda, D. S. (2014). Rio de Janeiro and the divided state: Analysing the political discourse on favelas. Discourse \& Society, 26(1), 74-94. DOI: $10.1177 / 0957926514541346$.

Larasati, T. (2014). Nomination and predication strategies employed by Islamic Republic of Iran Broadcasting (IRIB) in presenting news about Syrian civil war (a discourse historical approach). (Unpublished bachelor's thesis). Indonesia University of Education (UPI), Bandung, Indonesia.

Mancini, M. A. (2011). Understanding change in community mental health practices through critical discourse analysis. British Journal of Social Work, 41, 645-667. doi: 10.1093/bjsw/bcr067.

Matheson, D. (2005). Media Discourses: Analysing Media Texts (issues in Cultural and Media Studies). NY: Open University Press.

Merriam, S. (2009). Qualitative research: A guide to design and implementation. San Francisco: Jossey-Bass.

Paltridge, B. (2006). Discourse analysis: An introduction. London: Continuum.

Reisigl, M., \& Wodak, R. (2001). Discourse and discrimination: Rhetorics of racism and antisemitism. London: Routledge.

Signes, C. G. (2007). What do we laugh at? Gender representations in " 3 rd Rock from the Sun", International Perspectives on Gender and Language, 726-750.

Trčková, D. (2011). Representation of natural catastrophes in newspaper discourse: Portrayal of human-nature relationship. Unpublished doctoral dissertation, Masaryk University, Brno, Czech Republic.

Unger, J. W. (2010). Legitimating inaction: Differing identity constructions of the Scots language. European Journal of Cultural Studies, 13(1), 99-117.

van Dijk, T. A. (1988). News analysis: Case studies of international and national news in the press. Hillsdale: Lawrence Erlbaum Associates.

van Dijk, T. A. (2002). Political discourse and political cognition. In P. Chilton \& $\mathrm{C}$. Schaffner, (Eds.), Politics as text and talk: Analytic approaches to political discourse (pp. 203-237). Amsterdam: John Benjamins Publishing Company.

van Leeuwen, T., \& Wodak, R. (1999). Legitimizing immigration control: A discourse-historical analysis. Discourse Studies, 1(1), 83-118.

Vihersalo, K. (2009). The practices of representation: A comparison of Afghan women's identity in development policy magazines. (Unpublished bachelor's thesis). University of Jyväskylä, Jyväskylä, Finland.

Wenden, A. L. (2005). The politics of representation: A critical discourse analysis of 
an aljazeera special report. International Journal of Peace Studies, 10(2), 89-112.

Wodak, R. (2010). The glocalization of politics in television: Fiction or reality? European Journal of Cultural Studies, 13(1), 43-62. doi: $10.1177 / 1367549409352553$.

Wodak, R., \& Forchtner, B. (2014). Embattled Vienna 1683/2010: Right-wing populism, collective memory and the fictionalisation of politics. Visual Communication, 13(2), 231255. doi 10.1177/1470357213516720.

Wodak, R., \& Meyer, M. (2009). Critical discourse analysis: history, agenda, theory and methodology. In R. Wodak \& M. Meyer (Eds.), Methods of critical discourse analysis (pp. 1-33). London: Sage. 